\title{
Brazilian mangroves at risk
}

\author{
Felipe Polivanov Ottoni ${ }^{1 *}$, Robert M. Hughes ${ }^{2,3}$, Axel Makay Katz ${ }^{4}$, Filipe da Silva Rangel-Pereira ${ }^{4}$, \\ Pedro Henrique Negreiros de Bragança ${ }^{5}$, Rozijane Fernandes ${ }^{6}{ }^{\circledR}$, Ana Rita Onodera Palmeira-Nunes ${ }^{7}$, \\ Jorge Luiz Silva Nunes ${ }^{7}$, Ricardo Rodrigues dos Santos ${ }^{8 ®}$, Nivaldo Magalhães Piorski ${ }^{\circledR}$ \& \\ Jorge L. Rodrigues-Filho ${ }^{10,11}$ (1) \\ ${ }^{1}$ Universidade Federal do Maranhão, Centro de Ciências Agrárias e Ambientais, Laboratório de Sistemática \\ e Ecologia de Organismos Aquáticos, Campus Chapadinha, CEP 65500-000, BR-222, KM 04, Boa Vista, \\ Chapadinha, MA, Brasil. \\ ${ }^{2}$ Amnis Opes Institute, Corvallis, OR, USA \\ ${ }^{3}$ Oregon State University, Department of Fisheries \& Wildlife, Corvallis, OR, USA. \\ ${ }^{4}$ Universidade Federal do Rio de Janeiro, Instituto de Biologia, Departamento de Zoologia, Laboratório de \\ Sistemática e Evolução de Peixes Teleósteos, Cidade Universitária, CEP 21941- 599, Rio de Janeiro, RJ, Brasil. \\ ${ }^{5}$ South African Institute for Aquatic Biodiversity, Private Bag 1015, Grahamstown, Eastern Cape, South Africa. \\ ${ }^{6}$ Universidade Federal do Maranhão, Centro de Ciências Agrárias e Ambientais, Laboratório de Sistemática \\ Vegetal, Campus Chapadinha, CEP 65500-000, BR-222, KM 04, Boa Vista, Chapadinha, MA, Brasil. \\ ${ }^{7}$ Universidade Federal do Maranhão, Departamento de Oceanografia a e Limnologia, Laboratório de \\ Organismos Aquáticos, São Luís, MA, Brasil. \\ ${ }^{8}$ Universidade Federal do Maranhão, Centro de Ciências Agrárias e Ambientais, Laboratório de Comportamento \\ Animal, Campus Chapadinha, CEP 65500-000, BR-222, KM 04, Boa Vista, Chapadinha, MA, Brasil. \\ ${ }^{9}$ Universidade Federal do Maranhão, Departamento de Biologia, Laboratório de Ecologia e Sistemática de \\ Peixes, CEP 65080-805, Campus Dom Delgado, Avenida dos Portugueses, 1966, São Luís, MA, Brasil. \\ ${ }^{10}$ Universidade do Estado de Santa Catarina, Departamento de Engenharia de Pesca e Ciências Biológicas, \\ Laboratório de Ecologia, Rua Cel. Fernandes Martins, 270, Laguna, SC, Brasil. \\ ${ }^{11}$ Universidade do Estado de Santa Catarina, Programa de Pós-Graduação em Planejamento Territorial e \\ Desenvolvimento Socioambiental, Florianópolis, SC, Brasil. \\ *Corresponding author: Felipe Polivanov Ottoni, e-mail:fpottoni@gmail.com
}

OTTONI, F.P., HUGHES, R.M., KATZ, A.M., RANGEL-PEREIRA, F.S., BRAGANÇA, P.H.N., FERNANDES, R., PALMEIRA-NUNES, A.R.O., NUNES, J.L.S., SANTOS, R.R., PIORSKI, N.M., RODRIGUES-FILHO, J.L. Brazilian mangroves at risk. Biota Neotropica 21(2): e20201172.

https://doi.org/10.1590/1676-0611-BN-2020-1172

\begin{abstract}
Recent statements from the Brazilian federal government indicate that impacting economic activities, particularly commercial shrimp farming, are being encouraged in mangrove areas in the near future. Alterations of the National Action Plan and legal instruments that partially protected mangrove ecosystems have created an even weaker legal framework than previously existed. Such changes are leading Brazil far from the global call to conserve mangroves and from the Aichi targets and United Nations Sustainable Development Goals. Unfortunately, the loss of mangrove ecosystems and their ecosystem services will negatively impact living standards for Brazilians in coastal areas.
\end{abstract}

Keywords: Biodiversity, Carbon capture, Conservation, Nursery, PAN Manguezal.

\section{Manguezais brasileiros sob risco}

Resumo: As recentes determinações do governo Brasileiro indicam que atividades econômicas impactantes para os manguezais, particularmente a carcinocultura, serão incentivadas num futuro próximo. Alterações no Plano de Ação Nacional e em outros instrumentos legais, que parcialmente protegiam os manguezais, fragilizaram ainda mais os meios legais para proteção dessas áreas. Essas mudanças fazem o Brasil seguir na contra-mão da demanda global pela conservação dos manguezais e dos objetivos de desenvolvimento sustentável traçados pela Organização das Nações Unidas, bem como das metas de Aichi para a biodiversidade. Consequentemente, a iminente perda dos ecossistemas de manguezais impactará negativamente o padrão de vida dos Brasileiros que vivem em áreas costeiras. Palavras-chave: Berçário, Biodiversidade, Captura de Carbono, Conservação, PAN Manguezal. 


\section{Introduction}

Mangroves (Figure 1) represent highly productive ecosystems, once relatively common along tropical and subtropical oceanic coastlines, especially around estuaries, and currently present over an area about $181,000 \mathrm{~km}^{2}$ globally (Donato et al. 2011, Giri et al. 2011). Only about $2 \%$ of mangrove stands occur along temperate coastlines (Morrisey et al. 2010). Historically, several impacts have affected mangrove extents, such as: pollution, logging, and conversion to non-sustainable aquaculture and agriculture (Friess et al. 2019). Consequently, the global mangrove area, which is already smaller than previously estimated, continues to decline (Giri et al. 2011), making mangrove ecosystems top priorities for implementing conservation actions (Friess et al. 2019).

Mangrove ecosystems are characterized by transitional gradients of physiological and ecological characteristics, strongly influenced by salinity, nutrient concentrations, soil type, tidal amplitudes, and freshwater inputs, all of which create hostile conditions for most plant species (Walsh 1974, Cintrón \& Schaeffer-Novelli 1983, Araujo \& Pereira 2009, Silva et al. 2016). The vegetation is characterized by a homogeneous phytophysiognomy with low species diversity, but remarkable specializations in morphology and physiology (Figure 1) (Walsh 1974, Cintrón \& Schaeffer-Novelli 1983, Araujo \& Pereira 2009, Silva et al. 2016).

Brazilian mangrove plant associations are dominated by specialized species. These include some species of the genera Acrostichum L. (Pteridaceae), Avicennia L. (Acanthaceae), Cinnamodendron Endl. (Canellaceae), Conocarpus L. (Combretaceae), Crenea Aubl. (Lythraceae), Hibiscus L. (Malvaceae), Laguncularia C.F. Gaertn. (Combretaceae), Rhizophora L. (Rhizophoraceae), Spartina Schreb. (Poaceae), Spergularia (Pers.) J. Presl \& C. Presl (Caryophyllaceae), and Talipariti Fryxell (Malvaceae). Those species include herbaceous, shrubby, and woody plants (Schaeffer-Novelli \& Cintrón 1986, Bernini \& Rezende 2004, Martins et al. 2011, Santos et al. 2012, Flora do Brazil 2020) (Figure 1). Mangrove forest losses extirpate this unique and specialized flora.

\section{Range of Brazilian Mangroves}

In Brazil, mangrove areas occur along an extensive coastline, from the Oiapoque River mouth in the north, to Laguna, in Santa Catarina state, in the south (Saenger et al. 1983, Novelli et al. 2000, Maia et al 2006). Their Brazilian range represents $7 \%$ of the total global mangrove land cover (Giri et al. 2011). Considering only the Brazilian north coast, the country has the largest continuous formation of this ecosystem type in the world (Souza-Filho 2005).

\section{Ecosystem Services}

Many animal phyla and species use mangrove forests, such as molluscs, arthropods, fishes, reptiles, birds, and mammals (Giesen et al. 2006). For example, sixty-seven primate taxa, most of them exhibiting rare behaviors shelter or feed in tropical and subtropical mangroves (Supriatna \& Wahono 2000, Santos et al. 2019, Presotto et al. 2020). The high productivity rates of mangrove ecosystems are crucial for the benthic and pelagic components of neritic food webs (Robertson et al. 1992), providing direct and indirect resources (Tomlinson 1986, Luther $\&$ Greenberg 2009) for transient fishes and crustaceans as nursery and foraging habitats (El-Regal \& Ibrahim 2014, Hutchison et al. 2014, Sheaves 2017, Litvin et al. 2018). In particular, mangrove ecosystems are critical for sustaining economically valuable crustaceans (e.g., pink shrimps and swimming crabs), finfishes (e.g., snooks, mullets, sardines,

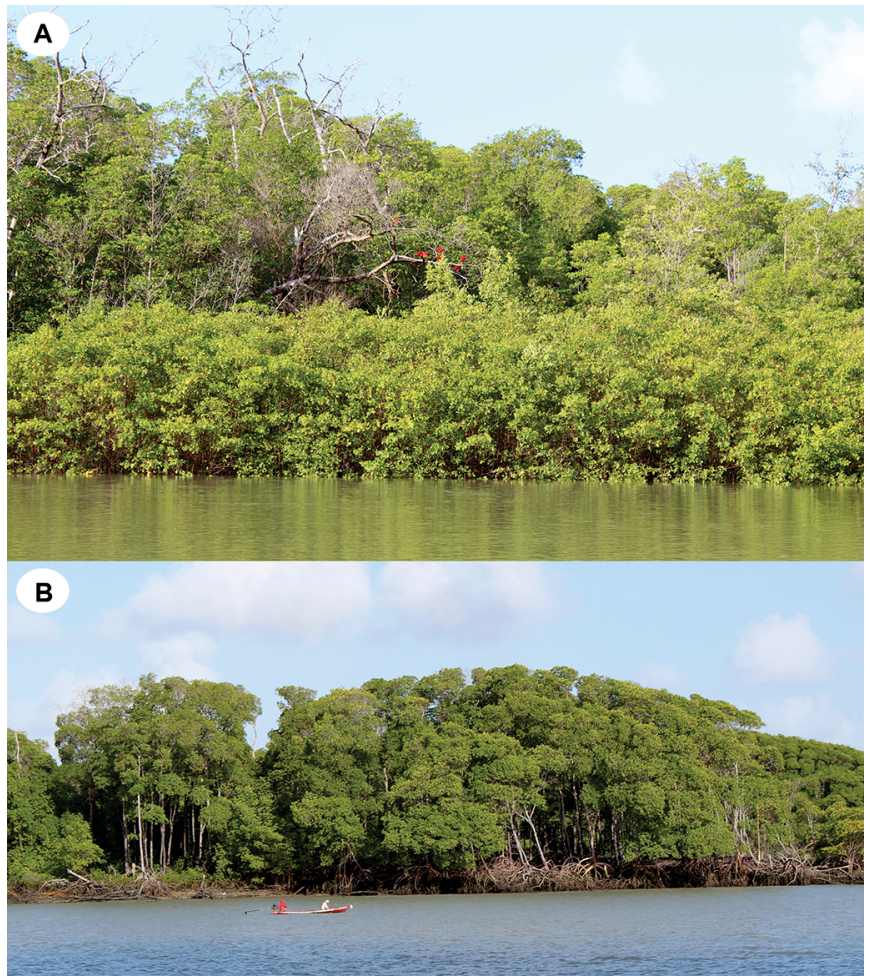

Figure 1. A (high tide) and B (low tide): mangroves in Cururupu locality, at Ilha dos Lençóis, archipelago of Maiaú, north Brazil. Photographed by Ricardo Rodrigues dos Santos.

some catfish species, snappers, several sciaenids, and some groupers), and their fisheries (Robertson \& Duke 1990, Sheridan 1992, Rogers \& Mumby 2019, Sheaves et al. 2020). In addition, mangrove forests provide several other ecosystem services, delivered to human society across local, regional and global extents (Barbier et al. 2011). These include such critically important services as erosion control, water purification, coastal protection from storms, raw materials and food, maintenance of fisheries, carbon sequestration and cultural services associated with tourism, recreation, education, and research (Figure 2).

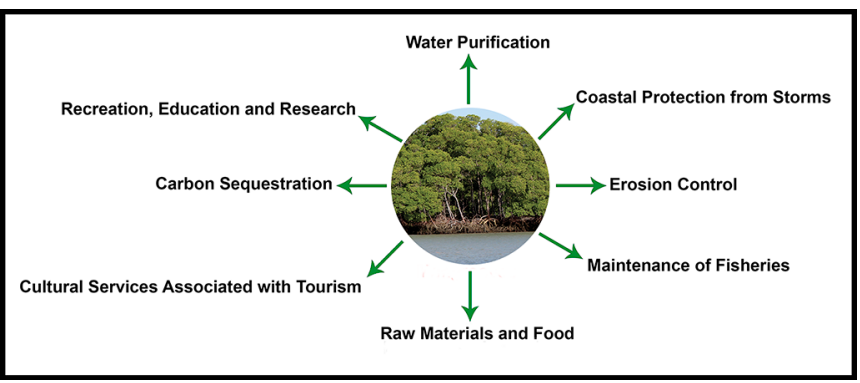

Figure 2. Representation of mangrove ecosystem services (green arrows) Water purification: Rybicki (1997), Lee \& Dunton (1999), Gacia et al. (1999), Cornelisen \& Thomas (2006), Romero et al. (2006), and Koch et al. (2006). Coastal protection: Fonseca \& Cahalan (1992), Koch (1996), Prager \& Halley (1999), Hemminga \& Duarte (2000), Spalding et al. (2003), and Koch et al. (2009). Erosion: Hemminga \& Nieuwenhuize (1990). Maintenance of fisheries: Cesar \& van Beukering (2004), and Zeller et al. (2007). Raw materials and food: Hemminga \& Duarte (2000), de la Torre-Castro \& Rönnbäck (2004), and Lauer \& Aswani (2010). Cultural Services associated with tourism: Naylor \& Drew (1998). Carbon sequestration: Freeman (2003), Pagiola et al. (2004), NRC (2005), Barbier (2007), U.S. EPA (2009), Mendelsohn \& Olmstead (2009), and Hanley \& Barbier (2009). Recreation: Mathieu et al. (2003). 
For example, Brazil has some conservation units in which mangrove forests play a major role in creating jobs and income, generating millions of reais per year through tourism, handcrafts, crab extraction, and traditional/commercial fishing. The Parque Nacional dos Lençóis Maranhenses (PNLM) and Delta do Rio Parnaíba (DRP) are both examples of areas that are benefited economically by ecosystem services provided from mangrove ecosystems. The PNLM received 151,786 tourists from all over the world in 2019 (ICMBIO 2020) to visit mainly sand dunes with freshwater lagoons, but also mangrove areas. In the DRP, crab extraction and commercial fishing are the main local economic activities, being the major location of crab harvest in Brazil (Legat et al. 2006, Fogaça et al. 2018).

\section{Legal Statute Concerns}

As with the global trend, Brazilian mangrove forests have been threatened for years, particularly by deforestation to build ponds for crustacean farming (Ferreira \& Lacerda 2016a). However, an astonishing set of recent events has further threatened these ecosystems, derived from an orchestrated sequence of Brazilian political decisions. Since the 2012 alterations in the Brazilian Forest Code (Código Florestal law 12.651/2012), mangrove ecosystems have not been fully protected (Ferreira \& Lacerda 2016b). Then, amidst the 2019 oil contamination crisis in coastal ecosystems (Escobar 2019) and government inability to protect the affected areas (Brum et al. 2020), the National Action Plan for Mangroves (Plano de Ação Nacional para a Conservação das Espécies Ameaçadas e de Importância Socioeconômica do Ecossistema Manguezal; PAN Manguezal) was altered. The PAN Manguezal, which identifies priority actions for ecosystem protection, was modified in 2019 to exclude the eradication of shrimp farming and the recovery of mangrove as goals. Later, in September 2020, the number of NGOs, universities and indigenous peoples represented in the National Environment Council (Conselho Nacional do Meio Ambiente; CONAMA) was reduced. The Bolsonaro government subsequently revoked
CONAMA resolution 303/2002, which established regulations to protect Brazilian mangrove ecosystems. These two recent changes have created a pathway for increasingly unregulated economic activities and impacts on mangrove ecosystems, leaving them without any protective regulations.

The PAN Manguezal and CONAMA changes imperil mangrove ecosystem services (see mangrove ecosystem services in Barbier et al. 2011) and, as a consequence, economic activities (e.g. tourism and commercial fisheries), that represent the main income and budget in several municipalities along the Brazilian coast. The Bolsonaro's government legal changes ignore global perspectives that consider mangroves as vitally important ecosystems for conservation (Friess et al. 2019). In addition, the new statutes are in opposition to the Aichi targets, which Brazil agreed to follow as part of the Convention on Biological Diversity, and the United Nations Sustainable Development Goals (SDGs). The SDGs are a set of goals aimed at reaching a sustainable planet that started to emerge during the 2012 United Nations Conference on Sustainable Development (Rio + 20), which occurred in Rio de Janeiro and brought together global leaders (Sachs 2015). In particular, the statutes violate four SDGs: SDG 2 (End hunger, achieve food security, improve nutrition, and promote sustainable agriculture); SDG 13 (Take urgent action to combat climate change and reduce its impacts); SDG 14 (Conserve and ensure the sustainable use and development of the oceans, seas, freshwater bodies and marine resources); and SDG 15 (Protect, restore and promote the sustainable use of terrestrial ecosystems, sustainably manage forests, combat desertification, halt degradation, and halt biodiversity loss). See Table 1 for a summary of the status of these statutes. The Brazilian government must reinstitute legal protections for mangrove ecosystems to abide by these global objectives. Otherwise, mangrove forests will be increasingly subjected to impacts that will threaten their biodiversity and the living standards of millions of Brazilian citizens living in coastal areas, whose lives depend on activities directly related to mangrove conservation.

Table 1. Summary of international and Brazilian mangrove related policies. Links in "Access" column direct to official government internet pages.

\begin{tabular}{lcccc}
\hline $\begin{array}{l}\text { International } \\
\text { Agreements }\end{array}$ & Main Resolves and Guidelines & $\begin{array}{c}\text { Regulating } \\
\text { Organ/ Event }\end{array}$ & $\begin{array}{c}\text { Implementation } \\
\text { Date }\end{array}$ & $\begin{array}{c}\text { Status in } \\
\text { January } \\
2021\end{array}$ \\
\hline
\end{tabular}

\begin{tabular}{|c|c|c|c|c|c|}
\hline $\begin{array}{l}\text { Aichi Biodiversity } \\
\text { Targets }\end{array}$ & $\begin{array}{c}\text { Target } 5 \text { - Halving of habitat loss } \\
\text { ratings; Target } 6 \text { - Sustainable } \\
\text { management of fisheries and } \\
\text { other seaborn stocks; Target } 11 \text { - } \\
\text { Conservation of at least } 10 \% \text { of } \\
\text { coastal and marine areas; Target } 14 \\
\text { - Restoration and safeguarding of } \\
\text { ecosystems that provide essential } \\
\text { services. }\end{array}$ & $\begin{array}{l}\text { Convention } \\
\text { on Biological } \\
\text { Diversity (1992 } \\
\text { Rio Earth } \\
\text { Summit) }\end{array}$ & January 2011 & Active & $\begin{array}{c}\text { https://www.cbd.int/sp/ } \\
\text { targets/ }\end{array}$ \\
\hline
\end{tabular}


Ottoni, F.P. et al.

\begin{tabular}{|c|c|c|c|c|c|}
\hline $\begin{array}{l}\text { Resolution CONAMA } \\
\text { No } 303 / 2002\end{array}$ & $\begin{array}{c}\text { Establishes mangroves as permanent } \\
\text { preservation areas. }\end{array}$ & $\begin{array}{l}\text { Conselho } \\
\text { Nacional do } \\
\text { Meio Ambiente } \\
\text { (CONAMA) }\end{array}$ & May 2002 & $\begin{array}{l}\text { Judicially } \\
\text { Active }\end{array}$ & $\begin{array}{l}\text { http://www2.mma.gov. } \\
\text { br/port/conama/legiabre. } \\
\text { cfm?codlegi=299 }\end{array}$ \\
\hline $\begin{array}{l}\text { Código Florestal (Law } \\
12.651 / 2012 \text { ) }\end{array}$ & $\begin{array}{c}\text { Allows and regulates implementation } \\
\text { of shrimp farms and salt pans } \\
\text { in mangroves and surrounding } \\
\text { environments. }\end{array}$ & $\begin{array}{l}\text { Ministério da } \\
\text { Casa Civil; } \\
\text { Ministério do } \\
\text { Meio Ambiente }\end{array}$ & May 2012 & Active & $\begin{array}{l}\text { http://www.planalto.gov. } \\
\text { br/ccivil_03/_ato2011- } \\
\text { 2014/2012/lei/112651.htm }\end{array}$ \\
\hline $\begin{array}{l}\text { PAN Manguezal } \\
\text { (ordinance ICMBio } \\
\text { No 9/2015) }\end{array}$ & $\begin{array}{l}\text { Establishes actions and directions } \\
\text { aiming for the conservation and } \\
\text { sustainable use of mangroves and } \\
\text { associated endangered species; } \\
\text { Specifically proposes erradication } \\
\text { of shrimp farms and salt pans in } \\
\text { mangroves. }\end{array}$ & $\begin{array}{l}\text { Instituto Chico } \\
\text { Mendes de } \\
\text { Conservação da } \\
\text { Biodiversidade } \\
\text { (ICMBio) }\end{array}$ & January 2015 & Revoked & $\begin{array}{c}\text { https://www.icmbio.gov. } \\
\text { br/cepsul/images/stories/ } \\
\text { legislacao/Portaria/2015/p_ } \\
\text { icmbio_09_2015_aprova_ } \\
\text { pan_manguezais.pdf }\end{array}$ \\
\hline $\begin{array}{l}\text { Resolution CONAMA } \\
\text { No } 500 / 2020\end{array}$ & $\begin{array}{l}\text { Revokes resolution CONAMA No } \\
\text { 303/2002. }\end{array}$ & $\begin{array}{l}\text { Conselho } \\
\text { Nacional do } \\
\text { Meio Ambiente } \\
\text { (CONAMA) }\end{array}$ & October 2020 & $\begin{array}{l}\text { Judicially } \\
\text { Suspended }\end{array}$ & $\begin{array}{c}\text { https://www.in.gov.br/en/ } \\
\text { web/dou/-/resolucao-conama/ } \\
\text { mma-n-500-de-19-de- } \\
\text { outubro-de-2020-284006009 }\end{array}$ \\
\hline
\end{tabular}

\section{Acknowledgments}

We are grateful to Dr. Valter Monteiro Azevedo dos Santos for constructive comments. FPO, RRS, and RF thank CAPES (Coordenação de Aperfeiçoamento de pessoal de nível Superior - Finance Code 001) and FAPEMA (Fundação de Amparo à Pesquisa e ao Desenvolvimento Científico e Tecnológico do Maranhão) for providing the financial and infrastructure support to carry out this work. JLSN thanks FAPEMA for his productivity scholarship, and AROPN thanks CAPES (Coordenação de Aperfeiçoamento de pessoal de nível Superior - Finance Code 001) for her Phd scholarship. JLRF thanks FAPESC (PAP2019031000116) for providing the financial and infrastructure support to carry out this work. RMH received a Fulbright Brazil grant.

\section{Author Contributions}

Felipe Polivanov Ottoni: Conceived the ideas; Manuscript writing.

Robert M. Hughes: Manuscript writing, language revision.

Axel Makay Katz: Manuscript writing.

Filipe da Silva Rangel-Pereira: Manuscript writing.

Pedro Henrique Negreiros de Bragança: Manuscript writing, language revision.

Rozijane Fernandes: Manuscript writing.

Ana Rita Onodera Palmeira-Nunes: Manuscript writing.

Jorge Luiz Silva Nunes: Manuscript writing.

Ricardo Rodrigues dos Santos: Manuscript writing.

Nivaldo Magalhães Piorski: Manuscript writing.

Jorge L. Rodrigues-Filho: Conceived the ideas; Manuscript writing.

\section{Conflicts of Interest}

The authors declare that they have no conflict of interest.

\section{References}

ARAUJO, D.S.D. \& PEREIRA, M.C.A. 2009. Sandy coastal vegetation. In: Del Claro K. et al. (Eds), Encyclopedia of Life Support Systems (EOLSS): tropical biology and conservation management - vol. IV, Oxford: EOLSSUNESCO, p. 173-189.

BARBIER, E. B. 2007. Valuing ecosystem services as productive inputs. Econ. Policy. 22: 177-229.

BARBIER, E.B., HACKER, S.D., KENNEDY, C., KOCH, E.W., STIER, A.C. \& SILLIMAN, B.R. 2011. The value of estuarine and coastal ecosystem services. Ecol. Monogr. 81(2): 169-183.

BERNINI, E. \& REZENDE, C.E. 2004. Estrutura da vegetação em florestas de mangue do estuário do rio Paraíba do Sul, Estado do Rio de Janeiro, Brasil. Acta bot. bras. 18: 491-502

BRUM, H.D., CAMPOS-SILVA, J.V. \& OLIVEIRA, E.G. 2020. Brazil oil spill response: Government inaction. Science. 367: 155-156.

CESAR, H. S. J. \& P. J. H. VAN BEUKERING. 2004. Economic valuation of the coral reefs of Hawai'i. Pac. Sci. 58: 231-242.

CINTRÓN, G. \& SCHAEFFER-NOVELLI, Y. 1983. Introduccion a la ecologia delmanglar. Montevideo, ROSTLAC, Unesco, 109p.

CORNELISEN, C.D. \& THOMAS, F. I. 2006. Water flow enhances ammonium and nitrate uptake in a seagrass community. Marine Ecology Progress Series 312: 1-13.

DE LA TORRE-CASTRO, M. \& RÖNNBÄCK, P. 2004. Links between humans and seagrasses: an example from tropical East Africa. Ocean Coast. Manag. 47: $361-387$.

DONATO, D.C., KAUFFMAN, J.B., MURDIUARSO, D., et al. 2011. Mangroves among the most carbon- rich forests in the tropics. Nat. Geosci. 4: 293-97. 
EL-REGAL, M.A.A. \& IBRAHIM, N.K. 2014. Role of mangroves as a nursery ground for juvenile reef fishes in the southern Egyptian Red Sea Egypt. J. Aquat. Res., 40 (1): 71-78.

ESCOBAR, H. 2019. Mystery oil spill threatens marine sanctuary in Brazil. Science. 366: 672.

FERREIRA, A. C. \& LACERDA, L.D. 2016a. Degradation and conservation of Brazilian mangroves, status and perspectives. Ocean Coast. Manag. 125: 38-46.

FERREIRA, A.C. \& LACERDA, L.D. 2016b. Reply to "On the impact of the Brazilian Forest Code on mangroves: A comment to Ferreira and Lacerda (2016)" by Ronaldo Ruy Oliveira-Filho et al. Ocean Coast. Manag. 132: 170-171.

FOGAÇA, F.H.S., FERNANDES-GÓES, L.C., SOUZA, L.O., SILVA, K.P., GOÉS, J.M., PEREIRA, A.M.L., MAI, M.G. \& MAGALHÃES, J.A. 2018. Monitoring mangrove crab Ucides cordatus Linnaeus, 1763 (Crustacea: Ucididae) landing in the Parnaíba River Delta: fishing characteristics, social and economic aspects. Nauplius. 26: e2018020. doi:10.1590/2358$2936 \mathrm{e} 2018020$

FONSECA, M. S. \& CAHALAN, J. A. 1992. A preliminary evaluation of wave attenuation for four species of seagrass. Estuarine, Coastal and Shelf Science 35: 565- 576.

FREEMAN, A. M., III. 2003. The measurement of environmental and resource values: theory and methods. Second edition. Resources for the Future, Washington, D.C., USA.

FRIESS, D.A., ROGERS, K., LOVELOCK, C.E., et al., 2019. The state of the world's mangrove forests: past, present, and future. Annu. Rev. Environ. Resour. 44: 89-115. doi: 10.1146/annurevenviron-101718-033302.

FRIESS, D.A., et al. 2020. Mangroves give cause for conservation optimism, for now. Curr. Biol. 30(4): R153-R154.

FLORA DO BRASIL 2020 em Construção. Jardim Botânico do Rio de Janeiro. Disponível em: http://floradobrasil.jbrj.gov.br. Access in: 09 nov. 2020.

GARCIA, E., GRANATA, T. KOCH, C. \& DUARTE, C. M. 1999. An approach to the measurements of particle flux and sediment retention within seagrass (Posidonia oceanica) meadows. Aquat. Bot. 65: 255- 269.

GIESEN, W., WULFFRAAT, S., ZIEREN, M. \& SCHOLTEN, L. 2006. Mangrove guidebook for Southeast Asia. FAO and Wetlands International, Bangkok. 769pp.

GIRI, C., OCHIENG, E., TIESZEN, L.L., ZHU, Z., SINGH, A., LOVELAND, T., MASEK, J. \& DUKE, N. 2011. Status and distribution of mangrove forests of the world using earth observation satellite data. Glob. Ecol. Biogeogr. 20: 154-159.

HANLEY, N. \& BARBIER, E. B. 2009. Pricing nature: cost-benefit analysis and environmental policy-making. Edward Elgar, London, UK.

HEMMINGA, M.A. \& NIEUWENHUIZE, J. 1990. Seagrass wrack-induced dune formation on a tropical coast (Banc-Darguin, Mauritania). Estuar. Coast. Shelf Sci. 31: 499- 502.

HEMMINGA, M.A. \& DUARTE, C.M. 2000. Seagrass ecology. Cambridge University Press, Cambridge, UK.

HUTCHISON, J., SPALDING, M. \& ZU ERMGASSEN, P. 2014. The Role of Mangroves in Fisheries Enhancement. Cambridge, UK, The Nature Conservancy and Wetlands International.

ICMBIO 2020, http://qv.icmbio.gov.br/QvAJAXZfc/opendoc2.htm?document=painel_corporativo_6476. qvw\&host=Local\&anonymous $=$ true

KOCH, E.W. 1996. Hydrodynamics of a shallow Thalassia testudinum bed in Florida, USA. Pages 105- 110 in J Kuo R. C Phillips D. I Walkerand H Kirkman editors. Seagrass biology: proceedings of an international workshop. Western Australia Museum, Perth, Australia.

KOCH, E.W., ACKERMAN J., VAN, KEULEN, M. \& VERDUIN, J. 2006. Fluid dynamics in seagrass ecology: from molecules to ecosystems. Pages 193- 225 in A. W. D Larkum R. J Orthand C. M Duarte editors. Seagrasses: biology, ecology and conservation. Springer-Verlag, Heidelberg, Germany.

KOCH. E.W., et al. 2009. Non-linearity in ecosystem services: temporal and spatial variability in coastal protection. Front. Ecol. Environ. 7: 29- 37.
LAUER, M. \& ASWANI, S. 2010. Indigenous knowledge and long-term ecological change: detection, interpretation, and responses to changing ecological conditions in pacific Island Communities. Environ. Manage. 45: 985- 997.

LEE, K.S. \& DUNTON, K.H. 1999. Inorganic nitrogen acquisition in the seagrass Thalassia testudinum: development of a whole plant nitrogen budget. Limnol. Oceanogr. 44: 1404- 1215.

LEGAT, J., MOTA, R., PUCHNICK, A., BITTENCOURT, C. \& SANTANA, W. 2006. Considerations about Ucides cordatus cordatus fishing in the Parnaíba River Delta Region, Brazil. J. Coast. Res. 3: 1281-1283.

LITVIN, S.Y., WEINSTEIN, M.P., SHEAVES, M., \& NAGELKERKEN, I. 2018. What makes nearshore habitats nurseries for nekton? An emerging view of the nursery role hypothesis. Estuaries Coast. 41(6): 1539-1550.

LUTHER, D.A. \& GREENBERG, R. 2009. Mangroves: a global perspective on the evolution and conservation of their terrestrial vertebrates. Bioscience. 59: 602-612.

MAIA, L.P., LACERDA, L.D., MONTEIRO, L.H.U. \& SOUZA, G.M.E 2006. Atlas dos manguezais do nordeste do Brasil: avaliação das áreas de manguezais dos Estados do Piauí, Ceará, Rio Grande do Norte, Paraíba e Pernambuco. v. 1. Fortaleza: SEMACE, 125 p.

MARTINS, P.T.A., COUTO, E.C.G. \& DELABIE, J.H.C. 2011. Fitossociologia e estrutura vegetal do manguezal do rio Cururupe (Ilhéus, Bahia, Brasil). J. Integr. Coast. Zone Manag. 11(2):163-169.

MATHIEU, L.F., LANGFORD, I.H. \& KENYON, W. 2003. Valuing marine parks in a developing country: a case study of the Seychelles. Environ. Dev. Econ. 8: 373- 390.

MENDELSOHN, R. \& OLMSTEAD, S. 2009. The economic valuation of environmental amenities and disamenities: methods and applications. Annu. Rev. Environ. Resour. 34: 325- 347.

MORRISEY, D.J., SWALES, A., DITTMANN, S., MORRISON, M.A., LOVELOCK, C.E. \& BEARD, C.M. 2010. The Ecology and Management of Temperate Mangroves. Oceanography and Marine Biology: An Annual Review. 48: 43-160.

NAYLOR, R. \& DREW, M. 1998. Valuing mangrove resources in Kosrae, Micronesia. Environ. Dev. Econ. 3: 471- 490.

NRC [National Research Council]. 2005. Valuing ecosystem services: toward better environmental decision making. National Academies Press, Washington, D.C., USA.

PAGIOLA, S., VON, RITTER, K. \& BISHOP, J. 2004. How much is an ecosystem worth? Assessing the economic value of conservation. World Bank, Washington, D.C., USA.

PRAGER, E.J. \& HALLEY, R.B. 1999. The influence of seagrass on shell layers and Florida Bay mudbanks. J. Coast. Res. 15: 1151- 1162.

PRESOTTO, A., REMILLARD, C., SPAGNOLETTI, N., SALMI, R., VERDERANE, M., STAFFORD, K., SANTOS, R. R., MADDEN, M., FRAGASZY, D., VISALBERGHI, E. \& IZAR, P. 2020. Rare Bearded Capuchin (Sapajus libidinosus) Tool-Use Culture is Threatened by Land use Changes in Northeastern Brazil. Int. J. Primatol. 41: 596-613. doi:10.1007/ s10764-020-00166-3.

ROBERTSON, A.I., ALONGI, D.M. \& BOTO, K.G. 1992. Food chains and carbon fluxes. In: ROBERTSON, A.I., ALONGI, D.M. (Eds.), Tropical Mangrove Ecosystems. American Geophysical Union, Washington DC, pp. 293-329.

ROBERTSON, A. I. \& DUKE, N. C. 1990. Mangrove fish-communities in tropical Queensland, Australia: spatial and temporal patterns in densities, biomass and community structure. Mar. Biol. 104: 369-379.

ROGERS, A. \& MUMBY, P.J. 2019. Mangroves reduce the vulnerability of coral reef fisheries to habitat degradation. PLoS Biol. 17, e3000510. doi: 10.1371/journal.pbio.30005 10.

ROMERO, J., LEE, K.S., PEREZ, M., MATEO, M. A. \& ALCOVERRO, T. 2006. Nutrient dynamics in seagrass ecosystems. Pages 227- 254 in A. W. D Larkum R. J Orthand C. M Duarte editors. Seagrass biology, ecology and conservation. Springer-Verlag, Amsterdam, The Netherlands. 
RYBICKI, N.B. 1997. Observations of tidal flux between submersed aquatic plant stand and the adjacent channel in the Potomac River near Washington, D.C. Limnology and Oceanography 42: 307- 317.

SACHS, J. 2015. The Age of Sustainable Development. Columbia University Press. New York. 565 p.

SAENGER, P., HEGERL, E.J. \& DAVIE, J.D.S., 1983. Global status of mangrove ecosystems. Environmentalist. 3: 7-80. doi: 10.1007/BF02340516

SANTOS, T.O., ANDRADE, K.V.S., SANTOS, H.V.S., CASTANEDA, D.A.F.G., SANTANA, M.B.S., HOLANDA, F.S.R. \& SANTOS, M.J.C. 2012. Caracterização estrutural de bosques de mangue: Estuário: Estuário do São Francisco. Scientia Plena. 8: 047315.

SANTOS, R.R. ARAUJO, A., FRAGASZY, D. \& FERREIRA, R. G. 2019. The role of tools in the feeding ecology of bearded capuchins living in mangroves. In: Katarzyna Nowak; Adrian Barnett; Ikki Matsuda. (Ed.), Primates in Flooded Habitats: Ecology and Conservation. pp. 179-190. Cambridge: Cambridge University Press.

SCHAEFFER-NOVELLI, Y. \& CINTRÓN, G.M. 1986. Guia para estudo de áreas de manguezal: estrutura, função e flora. [S.1.]: Caribbean Ecological Research. 186 p.

SCHAEFFER-NOVELLI, Y., CINTRON-MOLERO, G., SOARES, M.L.G. \& DE-ROSA, T. 2000. Brazilian mangroves. Aquat. Ecosyst. Health Manag. 3(4) : 561-570. doi: 10.1080/14634980008650693.

SHEAVES, M. 2017 How many fish use mangroves? The $75 \%$ rule an ill-defined and poorly validated concept. Fish Fish (Oxf), 18 (4). pp. 778-789.

SHEAVES, M., ABRANTES, K., BARNETT, A. BENHAM, C., DALE, P., MATTONE, C., SHEAVES, A., WALTHAM, N., \& BRADLEY, M. 2020. The consequences of paradigm change and poorly validated science: the example of the value of mangroves to fisheries. Fish Fish (Oxf), 21: 1067-1075.

SHERIDAN, P.F. 1992. Comparative habitat utilization by estuarine macrofauna with the mangrove ecosystem of Rookery Bay, Florida. Bull. Mar. Sci. 50: 21-39.
SILVA, S.F.L., SANTOS, M.A., LAGE-PINTO, F., BERNINI, E. 2016. Fitossociologia de uma floresta de mangue adjacente a uma planície hipersalina no estuário do Rio Miriri, Paraíba, Brasil. Revista Nordestina de Biologia, 24: 3-12.

SOUZA FILHO, P.W.M. 2005. Costa de Manguezais de Macromaré da Amazônia: Cenários Morfológicos, Mapeamento e Quantificação a partir de Dados de Sensores Remotos. Rev. Bras. de Geofis. 23: 427-435.

SUPRIATNA, J. \& WAHONO, E.H. 2000. Panduan Lapangan Primata Indonesia. Yayasan Obor, Jakarta.

SPALDING, M.D., TAYLOR, M., RAVILIOUS, C., SHORT, F. \& GREEN, E. 2003. The distribution and status of seagrasses. Pages 5-26 in E. P Greenand F. T Short editors. World atlas of seagrasses. University of California Press, Berkeley, California, USA.

TOMLINSON, P.B. 1986. The Botany of Mangroves. Cambridge University Press.

U.S. EPA [U.S. Environmental Protection Agency]. 2009. Valuing the protection of ecological systems and services. A report of the EPA Science Advisory Board. EPA, Washington, D.C., USA.

WALSH, G.E., 1974. Mangrove forests: a review. In: Reynold, R.J., Queen, W.H. (eds.). Ecology of Halophytes. New York, Academic Press.

ZELLER, D., S. BOOTH, G. DAVIS, \& PAULY, D. 2007. Re-estimation of small-scale fisheries catches for U.S. flag island areas in the Western Pacific: The last 50 years. US Fishery Bulletin (in press). Fish. Bull. (Wash. D. C.) 105(2): 266-277.

Received: $14 / 12 / 2020$

Revised: 10/02/2021

Accepted: 17/02/2021

Published online: 02/04/2021 